\title{
Trends in overweight and obesity in a representative sample of Irish adults
}

\author{
E. A. Boylan ${ }^{1}$, B. A. McNulty ${ }^{1}$, J. Walton ${ }^{2}$, A. Flynn ${ }^{2}$, A. P. Nugent ${ }^{1}$ and M. J. Gibney ${ }^{1}$ \\ ${ }^{1}$ UCD Institute of Food and Health, University College Dublin, Belfield, Dublin 4, Ireland and ${ }^{2}$ School of Food and \\ Nutritional Sciences, University College Cork, Cork, Ireland
}

Obesity is a serious and complex public health issue that can have a significant detrimental effect on health ${ }^{(1)}$. A BMI equal to or greater than $25 \mathrm{~kg} / \mathrm{m}^{2}$ defines overweight, while a BMI equal to or over $30 \mathrm{~kg} / \mathrm{m}^{2}$ defines obesity, according to the World Health Organisation $(\mathrm{WHO})^{(1)}$.

The aim of this research was to investigate trends in overweight and obesity in the Republic of Ireland. This was assessed using data from the Irish National Nutrition Survey (INNS, 1990) ${ }^{(2)}$, the North South Ireland Food Consumption Survey (NSIFCS, 2001) ${ }^{(3)}$ and the National Adult Nutrition Survey (NANS, 2011) ${ }^{(4)}$. BMI was determined as weight $(\mathrm{kg})$ divided by height $(\mathrm{m})$ squared and cut-offs defined according to the $\mathrm{WHO}^{(1)}$.

\begin{tabular}{|c|c|c|c|c|c|c|c|c|}
\hline & & Age group (years) & $n$ & $\begin{array}{c}\text { Underweight } \\
\qquad(\%) \\
\leq 18.49\end{array}$ & $\begin{array}{c}\text { Normal } \\
(\%) \\
18.5-24.9\end{array}$ & $\begin{array}{c}\text { Overweight } \\
(\%) \\
25.0-29.9\end{array}$ & $\begin{array}{l}\text { Obese } \\
(\%) \\
\geq 30\end{array}$ & $P$-Value* \\
\hline INNS & All & $18-64$ & 590 & 1.7 & 49.5 & 38.1 & 10.7 & \\
\hline NSIFCS & & $18-64$ & 1311 & 0.8 & 42.4 & 39.0 & 17.8 & \\
\hline NANS & & $18-64$ & 1165 & 0.8 & 38.5 & 37.3 & 23.5 & $<0.05$ \\
\hline $\begin{array}{l}\text { INNS } \\
\text { NSIFCS } \\
\text { NANS }\end{array}$ & Men & $\begin{array}{l}18-64 \\
18-64 \\
18-64\end{array}$ & $\begin{array}{l}256 \\
613 \\
573\end{array}$ & $\begin{array}{l}0.4 \\
0.3 \\
0.3\end{array}$ & $\begin{array}{l}41.0 \\
33.3 \\
30\end{array}$ & $\begin{array}{l}50.8 \\
46.3 \\
43.8\end{array}$ & $\begin{array}{r}7.8 \\
20.1 \\
25.8\end{array}$ & \\
\hline $\begin{array}{l}\text { INNS } \\
\text { NSIFCS } \\
\text { NANS }\end{array}$ & Women & $\begin{array}{l}18-64 \\
18-64 \\
18-64\end{array}$ & $\begin{array}{l}334 \\
698 \\
592\end{array}$ & $\begin{array}{l}2.7 \\
1.1 \\
1.2\end{array}$ & $\begin{array}{l}56.0 \\
50.4 \\
46.6\end{array}$ & $\begin{array}{l}28.1 \\
32.5 \\
30.9\end{array}$ & $\begin{array}{l}12.9 \\
15.9 \\
21.3\end{array}$ & $<0.05$ \\
\hline
\end{tabular}

The prevalence of obesity in Irish adults has increased approximately 2.2-fold during the last three decades. This trend is evident for both men (3.3-fold increase) and women (1.7-fold increase). In contrast, the prevalence of normal weight has decreased between 1990 (INNS) and 2011 (NANS) for the total population and for both men and women. Significant changes in the proportion of the population classified as overweight were also observed.

These results highlight the growing trend of obesity in Irish adults. Effective treatment and prevention strategies are needed to avoid further increases in the next decade.

This study was funded by the Irish Department of Agriculture, Fisheries and Food under the Food for Health Research Initiative (2007-2012).

1. World Health Organisation (WHO) (1998). Obesity: Preventing and Managing the Global Epidemic. WHO/NUT/NCD/98.1. Geneva: WHO.

2. Lee P \& Cunningham K (1990) The Irish National Nutrition Survey 1990. Dublin: Irish Nutrition and Dietetic Institute.

3. McCarthy SN, Harrington KE, Kiely M et al. (2001) Public Health Nutr 4,1099-1106.

4. Irish Universities Nutrition Alliance (2011) The National Adult Nutrition Survey. http://www.iuna.net 